\title{
Are floods in part a form of land use externality?
}

\author{
W. Dorner ${ }^{1}$, M. Porter ${ }^{2}$, and R. Metzka ${ }^{1}$ \\ ${ }^{1}$ Water and Environment, University of Applied Sciences Deggendorf, Germany \\ ${ }^{2}$ Australian Centre for the Sustainable Catchments, University of Southern Queensland, Australia
}

Received: 1 October 2007 - Revised: 11 January 2008 - Accepted: 12 January 2008 - Published: 27 May 2008

\begin{abstract}
Peak and volume of river flows are functions of the catchment surface characteristics. This means that any impacts to the run-off regime (for example surface sealing and river training) could affect people and land users in the lower system. The costs of flood defence or compensation of damages are usually not included in the economic calculation of the upstream land owner or land user. In economic terms these effects are referred to as unidirectional externalities. This paper presents a methodology to identify externalities related to land use and run-off and describes the relevant cause-effect relations and how they can be modelled. The Herzogbach is a small tributary of the Danube River in Lower Bavaria. It is located in a rural area, dominated by intensive farming practices. A combination of hydrological and hydraulic modelling provided the core of the project methodology to allow the interpretation of economic data. Comparisons of damage estimates resulting from different hydrological scenarios based on different land uses, and flood mitigation costs were used to show the economic significance of human impacts.
\end{abstract}

\section{Introduction}

On a river basin scale the upper catchment is linked to the lower system via hydrological processes and the river system. Land use such as agriculture, settlement, but also river training, detention and other flood protection are examples of human impacts that influence the run-off regime in this system. In the linked environment of a river basin, upstream actions can influence downstream stakeholders. Effects of land sealing, draining, river development and diked floodplains have been evaluated during the last years. Specific statements about the level of increase of floods can not be

Correspondence to: W. Dorner

(wolfgang.dorner@fhd.edu) made, but it can be stated, that depending on the local situation in the catchment all these effects cause an increase of flood peaks and the shape of a flood wave. On a plot and micro scale these dependencies have been proven, on a meso scale they can be quantified and on a macro scale they can be estimated.

These effects of land use on flood development and the resulting damages or mitigation costs can be called an externality of land use. If we take a rivulet or river as a system with a unidirectional transmission of effects from the head to the tail water, land users can fully export their costs of production in the form of run-off to the people downstream. From an economic point of view the extent of flood related costs such as flood damages or flood defence are of interest and how natural effects can be distinguished from human impacts, which represent the external cost. This is of importance to evaluate whether and how legal and market oriented counter measures, called internalization, can be used.

\section{Theory of externalities}

In a market based economy goods are allocated via markets. Prices are indicators for the demand for a good and for its scarcity. In a perfect market the market price causes an optimal allocation of resources and an optimal welfare of all market participants. The theoretical assumption of a perfect market includes the idea that all market actions only affect participants of this market.

In reality often other people are affected by market actions. In economic theory costs and benefits, that are not included in the production costs and are exported to third parties, for example pollution and its social costs, are called externalities. They exist because people can use a resource without compensation for its use. "An externality arises when a person engages in an activity that influences the wellbeing of a bystander and yet neither pays nor receives any

Published by Copernicus Publications on behalf of the European Geosciences Union. 
compensation for that effect" (Mankiw, 2003, p. 204). Two types of externalities are possible, depending on whether the effect on the bystander is positive or negative. Externalities represent market failures or imperfections, because equilibrium in market forces is not possible. "The equilibrium fails to maximize the total benefit to society as a whole" (Mankiw, 2003, p. 204). "Externalities cause markets to allocate resources inefficiently" (Mankiw, 2003, p. 205). Externalities also exist in the form of spatial externalities and inter temporal externalities. Most actions take place in one area or time, but the effects are transferred to another area or generation.

Public and private solutions exist to avoid market failures from externalities or to reduce their effects. These solutions involve a process called internalisation, which means that political, social or economic instruments are used to include the external costs in the economic model. Private solutions can be based on moral or social codes like charities, contracts, bargaining or negotiation (Mankiw, 2003; Cansier, 1996; Endres, 2000). Command and control strategies are used to regulate markets, establish emission levels or ban practices, as alternatives to market oriented solutions such as certificates.

Water use or the use of water bodies can be subdivided into two main types: direct and indirect use. Direct use includes all types of use, where water becomes directly part of the product or is consumed in the process of production. Indirect use includes all type of uses, where water is influenced as a side effect of the production, where the water "use" has no direct impact on the success or failure of the production process and the resulting product. Direct uses include for example hydro power, irrigation or washing water for vegetables. A typical form of indirect use is erosion on agricultural sites. Excessive rainfall does not play a role for the success of agriculture. Instead during such events most rain water is lost, because of low infiltration and fast surface run-off. Through the erosive processes and the transport of sediments, nutrients and pesticides, water bodies and downstream riparians are influenced, because they have to bear the costs for sediment removal or damages due to sediments during flooding.

Because of the upstream downstream situation in a river basin, an upstream user will only marginally be affected by its own action, while downstream users have to deal with the full effect of upstream activities. As well as local or regional dimension, externalities can also play a crucial role in international river basins. While national regulations and actions have a national economic consequence, they can strongly affect the political situation between two states.

Each person upstream influences or can influence the quantitative, qualitative availability and the temporal and spatial distribution of water available to a downstream user. Acting and affected persons can thereby be individuals in small catchments, regions in medium size catchments or even countries in the catchments of big streams.

To analyse the resulting effects of human actions makes it necessary to compare the different individual and societal situations resulting from different options to act. CostBenefit-Analysis (CBA) can be used to compare economic outcomes of different scenarios as well as environmental situations. $\mathrm{CBA}$ is a standard instrument in natural hazard management and suggested as a basis for flood mitigation projects (Gamper et al., 2006; Schmidtke, 1981). "The essential theoretical foundations of CBA are: benefits are defined as increases in human wellbeing (utility) and costs are defined as reductions in human wellbeing. For a project or policy to qualify on cost-benefit grounds, its social benefits must exceed its social costs." (Pearce et al., 2006, 16). But it is also bound to several restrictions. The calculated or assumed costs and benefits depend on different limitations and restrictions like the definition of the geographical boundries of the evaluation, inter-temporal effects or preferences of individuals and groups of individuals. Umweltbundesamt (2007) names the evaluation of irreversible damages, the choice between different types of cost categories and the quantification of potential risks as examples of problems to evaluate and estimate costs and benefits. Therefore, CBA can only give an impression of the total extent of externalities.

\section{Processes on a catchment scale}

"The hydrologic cycle describes the movement of water in all its states of aggregation from precipitation, over evapotranspiration, infiltration, surface run-off. Human actions like agriculture, settlement and infrastructure influence this cycle and increase, especially in small catchments, the flood peaks. The development of floods is highly dependant on surface structures, soil type and land cover. In densely settled areas the percentage of sealed surface is the important factor. In rural regions the type of fruits and plant cover influences mainly the run-off." (Dorner et al., 2005, p. 27)

Different human actions happen in the catchment and along the river reaches. They affect hydrological sub processes such as evaporation, infiltration and surface run-off, as well as the hydraulic conditions for discharge in water courses.

Scheidleder et al. (1996) aimed to detect the effects of human interventions on the hydrologic cycle depending on the Biogeographic Regions (Boreal, Atlantic, Continental, Alpine, Mediterranean, Macronesian) in Europe. Selected member states of the European Union including Denmark, France and Austria participated in this survey. State administrations were asked to answer questions about the level of interventions, measured impacts on the hydrological cycle and the reasons for these interventions. Three types of interventions were identified in the study, as they are

- river, lake and estuary regulation,

- water abstraction,

- activities in the catchment. 
"Land sealing by urbanisation and land drainage for cultivation occur in each of the proposed regions and, where it occurs, seem to be most important activities in the catchment." summarizes Scheidleder et al. (1996) in the outcomes of the European study.

Human actions like land use and river training have occurred over several decades and influenced different sub processes within the hydrological cycle. Starting with the catchment especially land clearance, farming and urban development changed the surface, infiltration capacity, small runoff relevant structures like depressions and drains as well as run-off paths in the landscape. The Umweltbundesamt (2001) performed a study to identify the impacts of land use on run-off and flood development. Three sub catchments, Lein $115 \mathrm{~km}^{2}$, agricultural and flat to hilly, Körsch $127 \mathrm{~km}^{2}$ as a mainly settled area, Lenne $455 \mathrm{~km}^{2}$ with a hilly catchment and mainly forestry were assessed. The main objective of the study was to detect the effect of different land use types on run-off development and floods. Different future land use scenarios were forecast using a model, combining a prediction of the quantitative change and a spatial analysis for the local area development. Models predicted a trend of increased urbanisation and the use of more intensive agricultural techniques. Results of the hydrological model showed that depending on the type of precipitation an increase of settled areas by $50 \%$ can increase flood peaks up to $30 \%$. A historic scenario for land use strucutures $(1.3 \%$ settled areas in 1836 in contrast to $25 \%$ today) showed that a real flood event from 1992 would have had only a fraction of its real peak in 1836.

Auerswald (2002) measured the impacts of different farming practices on surface run-off. He compared classical techniques with new systems like intermediate crops. In parallel to a reduction of soil erosion he also detected a decrease of surface run-off.

Dyck (1995) describes the enormous losses of detention along the Elbe River during the last 800 years. He points out that the efforts to compensate these lost volumes through technical detention measures are insignificant. These human activities result in economic consequences for downstream riparian users. "Construction of a levee can channelize a river so that during flood stage the flow of water is swifter and sent downstream where it does more damage than if the upstream levee were not constructed. Thus, the decision of community $\mathrm{X}$ to construct a levee may impose an external cost on downstream community $\mathrm{Y}$ though greater flood damage, higher levee construction costs, or both." states Agthe et al. (2000) about this problem. The same idea can be applied to all upstream activities affecting downstream parties. The main problem is how to estimate the extent of the externality?

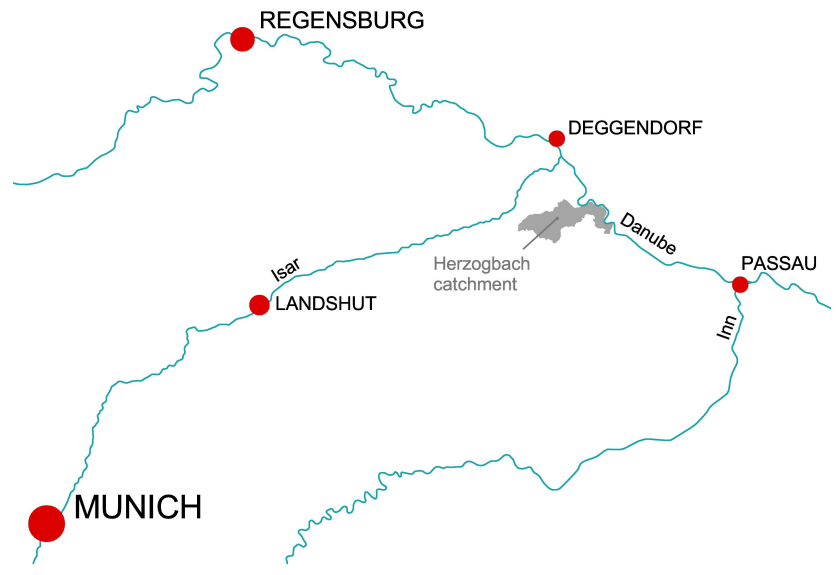

Fig. 1. Situation of the Herzogbach catchment in the Danube catchment.

\section{Study area}

These dependencies have been evaluated for a small rural catchment with $72 \mathrm{~km}^{2}$ catchment size. The Herzogbach catchment is located in southern Bavaria (Germany) near the city of Deggendorf as shown in Fig. 1. The main river reach has a length of about $20 \mathrm{~km}$. It flows from west to east through a hilly landscape. The Herzogbach and all its tributaries originate in the southern hilly landscape. The areas in the upper reaches are rural with about $80 \%$ agriculture and $5 \%$ forestry. Settlements are mainly located in the flat depressions along the rivulets. The lower river passes through the city of Osterhofen, where it has cause severe damages in the past major floods. The Herzogbach ends in the floodplain of the Danube and has its outlet into the Danube near the city of Vilshofen.

Except on the flood plains, land use has developed according to the geomorphology (Fig. 2). The top of the tertiary hilly landscape in the south of the catchment is mainly used for forestry. The open plains of the Gäuboden provided better conditions for farming, because of the fertile soils and the possibility to establish big field units. Up to the late 19th century agriculture was dominated by the three-field crop rotation (Herbert and Maidl, 2005, p. 277). The changes in the agricultural production were induced by new technological developments and scientific findings. The implementation of new fertilizers caused a change of the old crop rotation scheme to a rotational cropping system. The mechanisation of agriculture lead to land reallocation projects to increase the size of fields. New harvesting techniques, the development of pesticides and of new crops also influenced the types of plants used in the local agriculture. Maize, beet, vegetables and wheat are now the dominant crops, superseding clover and crop types like rye and oat (Herbert and Maidl, 2005, p. 278 ff.). The changes also led to a specialisation 


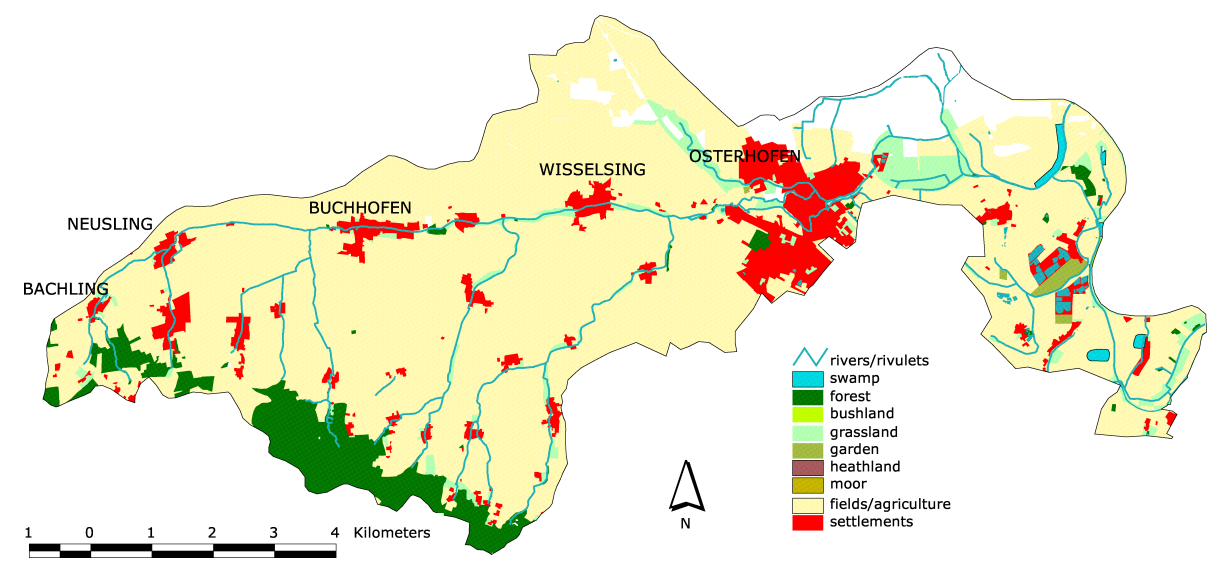

Fig. 2. Herzogbach catchment and the distribution of land use.

on agriculture and replaced livestock farming (Herbert and Maidl, 2005, p. 295 et sqq.). Meadows and pastures were converted to fields. Land clearance projects in the 1960s and 70 s changed plots sizes and structures, trained rivulets and rivers and established drains to optimize agricultural production. In addition to infrastructure development and settlement these processes changed the hydrological characteristics of the catchment.

\section{Methodology}

The Umweltbundesamt (2007) describes a standardized approach for the analysis and evaluation of externalities in Germany. The authors propose a methodology in seven steps:

\section{Definition of objectives}

2. Specification of the subject of analysis and the boundaries of the system

\section{Description of impacts}

\section{Description of cause-effect relations}

5. Allocation of economic benefit and cost categories

6. Economic interpretation of resulting changes in benefits

7. Interpretation and comparison of damages with internalized costs

Because of the complexity of the analysis of processes in the catchment and the flood plain, this paper will concentrate especially on items 1-4 above. This study concept partially applies this methodology to the situation in the test catchment. A combination of hydrological model, hydrodynamic model and economic assessment was used. With a combination of hydrological regionalisation, flood and pond routing different land use and river structure scenarios have been evaluated and their effect on the flood behaviour was identified. In a second step impacts of these flood waves on settled areas have been simulated using a hydrodynamic 2D stream flow model. Lastly an economic comparison was made of land use and flood defence scenarios to estimate the amount of land use externalities using cost estimates of flood damages and mitigation costs for different hydrological scenarios. This simplified methodology to calculate flood damage scenarios and avoidance costs was chosen because of the complexity of a full evaluation of externalities which would go beyond the scope of this paper.

\subsection{Hydrological analysis}

Main intention of the study is to identify the impact of land use and river development in the headwaters on people and property in the lower reaches. There is insufficient statistical hydrological data available for such an analysis for any known catchment because of the long history of land clearance and agricultural development. The lack of statistical data can be compensated using hydrological models.

Hydrological models simulate the run-off development in a catchment based on statistical or real time precipitation values. Input data include the duration and intensity of precipitation and the state of all surfaces in the catchment as defined by slope, surface roughness and soil conditions. For areas that lack recorded water levels, such models provide the design data to develop flood mitigation systems, in particular the volume and temporal information needed for the design of retention basins.

The computer model used for this study is a conceptional deterministic river basin model to simulate precipitation-runoff processes in small and medium size catchments. "Deterministische konzeptionelle Flussgebietsmodell für den Abfluß setzen sich nach dem Baukastenprinzip aus Verfahren zur Simulation verschiedener Teilprozesse zusammen. [Deterministic conceptual river basin models for 


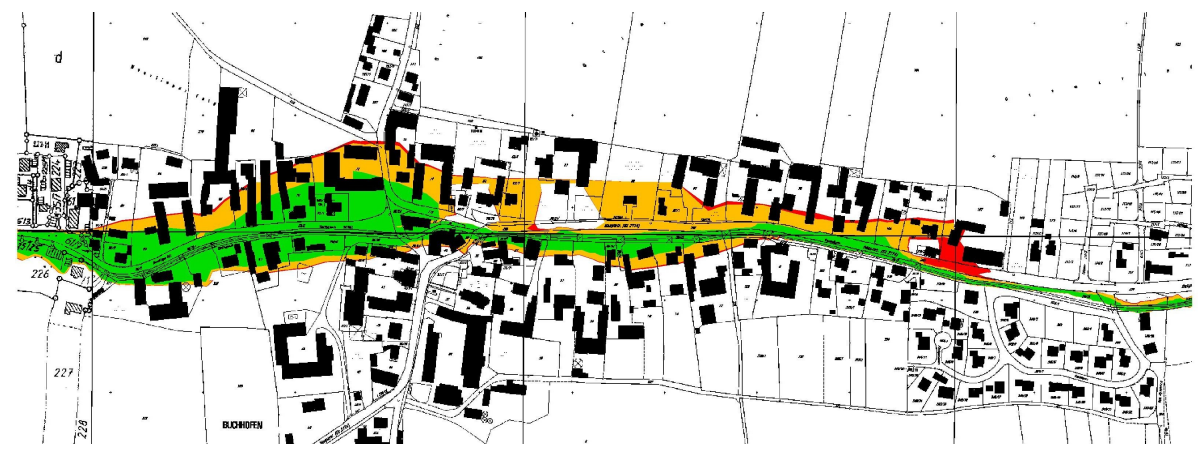

Fig. 3. Flood plain in Buchhofen for a 10 year flood event with floodings resulting from scenario A (red), B (yellow) and C (green).

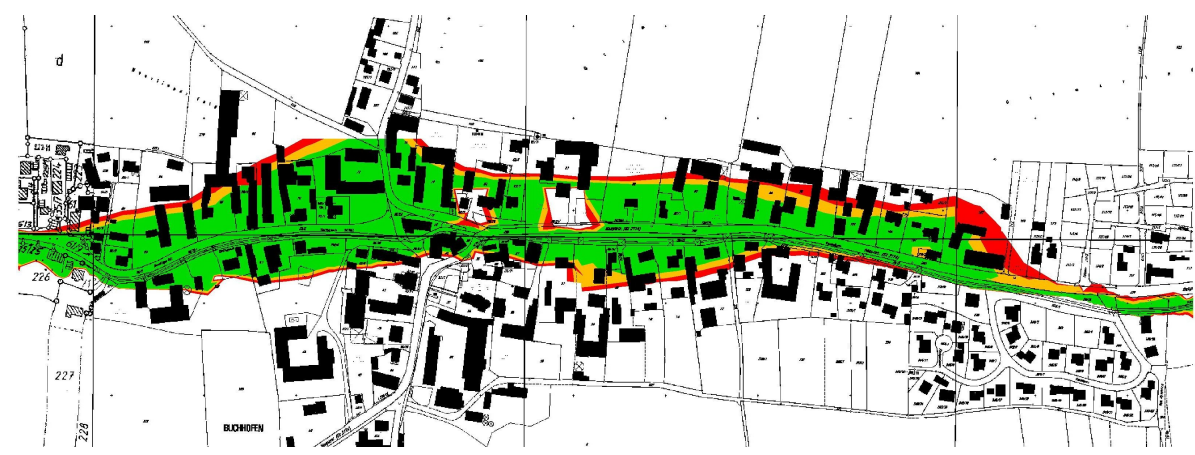

Fig. 4. Flood plain in Buchhofen for a 100 year flood event with floodings resulting from scenario A (red), B (yellow) and C (green).

discharge simulation are modular systems to simulate different processes.]"(Maniak, 1993, p. 361). The applied model consists of three elements:

- the regionalisation approach by Lutz (Ihringer, 2002) to calculate losses from evapotranspiration, and infiltration and derive a flood wave as a hydrograph for each sub basin,

- Kalinin-Miljukov (Ihringer, 2002) as a flood routing approach to estimate the superposition of flood waves from sub basins and simulate the detention of the river reach and flood plain,

- a reservoir routing approach to check the efficiency of detention measures.

A first landscape model was derived as scenario A, representing the status quo for land use and river structure of the catchment (Table 1). In a second step the model was modified to simulate different scenarios. First change was a modification of land cover to simulate a catchment similar or close to the natural predevelopment status providing scenario B. For a natural status of the landscape a mixture of forest and meadow with an emphasis on dense primeval forest would be realistic. An analysis of historic maps showed
Table 1. Hydrological scenarios.

\begin{tabular}{llll}
\hline Scenario & Land use & River & Reservoirs \\
\hline A & status quo & status quo & no \\
A1 & status quo & status quo & existing \\
B & Pasture and forest & status quo & no \\
C & Pasture and forest & natural & no \\
C1 & Pasture and forest & natural & existing \\
\hline
\end{tabular}

that the change in forested areas is minor and that this stock was unchanged over 200 years. Due to the actual situation, where a redevelopment of wide areas into forest would be unrealistic and the uncertainty about the exact distribution of land cover, an assumption was made: Areas covered with trees remained as forests in the model; agricultural sites and sealed areas were transformed into meadow and fallow.

In a next step scenario $C$ was derived as a modification of the river structure in addition to a redeveloped land cover. Old maps from the early 1820 s showed very well, which modifications of the river structure took place over years. While in the 18 century the rivers showed a natural meandering structure with a wide meadow flood plain, the actual situation shows degraded structures using technical profiles and 
Table 2. Detention reservoirs in the catchment

\begin{tabular}{|c|c|c|c|c|}
\hline $\mathrm{Nr}$. & Protected city & Volume & Node & Status \\
\hline $\mathrm{P} 1$ & Bachling & & 2 & Planned \\
\hline $\mathrm{P} 2$ & Bachling & & 4 & Planned \\
\hline P3 & Buchhofen & & 14 & Planned \\
\hline
\end{tabular}

stretched flow lines. Historic maps were used to provide data to represent the river structure in the model for historic and natural situations. The analysis showed that a natural river system would have been minimum 1.2 and up to 1.5 times longer than today. The prolongation depends very much on the location of the river section in the head or main stream, the severity of human intervention later on and the steepness and geology of the landscape. But also the historic maps showed very early human intervention on the river structure, which made it very difficult to reconstruct the original status for each individual section. Therefore, an extension of $20 \%$ was assumed for all sections. No data about historical profiles of the rivulet are available. In the whole catchment no representative natural sections of the river system remainded to allow an assumption for each profile type. Renaturalized river sections show that the natural profile would not be so deep, and would have lower and flatter embankments. Unfortunatley these sections have been redeveloped and are not old enough to show the natural profile. Therefore, the measured profiles of the status quo were used for the historical situation, too.

Three potential locations for detention reservoirs (Table 2) were identified and modelled in the catchment to assess efficiency of detention under different hydrological scenarios.

\subsection{Hydrodynamic modelling}

Hydrodynamic computer modelling numerically solves complex stream flow equations to calculate the water level and direction of the stream-flow for a defined terrain and flow. Outputs can be presented as tables of water level, direction and speed values, but also as maps of flooded areas showing water depths in different colours. Hydraulic models help to identify flood endangered areas and allow the assessment of protection mechanisms like levees, dams or bypasses to be checked.

In Bavaria the SMS - HydroAS-2D software package (Nujic) is a standard system used for 2-D hydrodynamic flood routing. It is based on the SMS - Surface Water Modelling System developed by the Environmental Modeling Research Laboratory at Brigham Young University as preprocessor and interface. It includes a pre- and a post-processor for two- and three-dimensional finite element and finite difference models.
Table 3. Scenarios and results for Bachling.

\begin{tabular}{llll}
\hline Scenario & Peak flow & Reservoir volume & Costs for detention \\
\hline A & $1.5 \mathrm{~m}^{3} / \mathrm{s}$ & $3900 \mathrm{~m}^{3}$ & 117000 Euro \\
B & $1.2 \mathrm{~m}^{3} / \mathrm{s}$ & $2000 \mathrm{~m}^{3}$ & 60000 Euro \\
C & $1.1 \mathrm{~m}^{3} / \mathrm{s}$ & $1800 \mathrm{~m}^{3}$ & 54000 Euro \\
\hline
\end{tabular}

\subsection{Economic assessment}

The economic analysis of externalities using CBA is bound to several theoretical and practical problems described above. Because the main focus of the study was the identification of cause-effect relations and the development of a methodology to identify externalities not a full CBA was performed. Flood damages and flood mitigation costs were used to get a first estimate of the extent of externalities resulting from land use and related changes in the hydrology of the catchment. A CBA was considered to be the necessary next step if the technical and economic results presented in this paper prove the existence of significant impacts.

Flood damages, costs of flood detention and the costs for in situ flood mitigation measures in settled areas can be used, to assess the economic impacts and derive the extent of externalities. Because floods have also a natural non-human component not all costs can be used for the estimation of externalities. The costs, resulting from protection against or the damages of natural flood events, must be subtracted from the costs of a flood event increased by human activities.

Kelman and Spence (2004) separate indirect flood damages like business interruption or changed spending patterns from direct damages caused by forces, pressures or chemical reactions to objects or persons. In the project area no infrastructure of superior interest (highways, pipelines, railways, telecom,...) will be affected by floods. Mainly farms and residential buildings and almost no businesses are located in the flood plain. Therefore, the majority of damages will result from direct damages to buildings and furniture.

\section{Analysis}

\subsection{Village of Bachling - Consequences for flood mitiga- tion}

Bachling represents the type of small village in the steeper upper part of the catchment (Tertiary Hilly Landscape). In the hydrologic model only one sub-catchment is of relevance for the run-off and flood development in the settlement. It has a size of $1.2 \mathrm{~km}^{2} .72 \%$ of the catchment are fields and mainly used for root crops and vegetables without intermediate crops (result of inspections in summer and early autumn 2004 and 2005). $15 \%$ of the catchment is covered by forest, $12 \%$ by grassland and less than $1 \%$ is sealed. The rivulet is straight and has already a deep river bed between 1 and $1.4 \mathrm{~m}$ below the flood plain. 


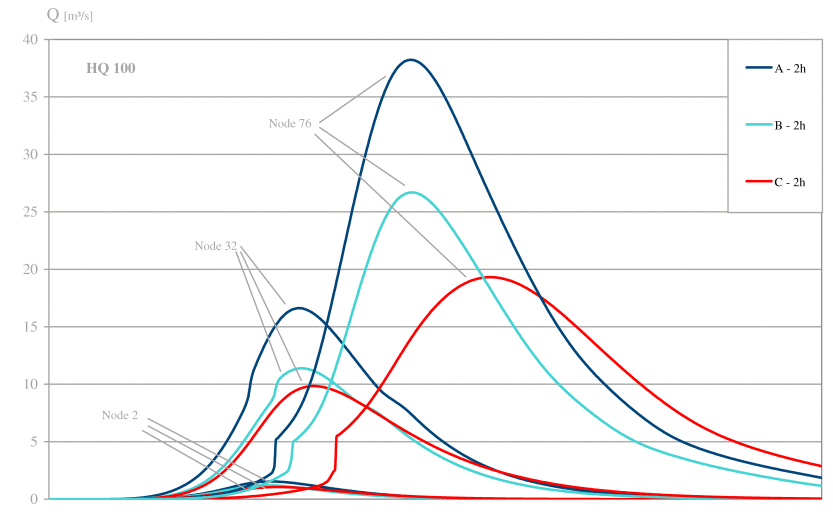

Fig. 5. Flood waves for scenarios $A, B$ and $C$ in the headwater (Node 2 - Bachling), middle section (Node 32 - Buchhofen) and tail water (Node 76).

The peak of $1.5 \mathrm{~m}^{3} / \mathrm{s}$ of the status quo scenario (Scenario A) for a 100 year flood event is mainly influenced by land use. The catchment with natural land cover would result in a peak of $1.2 \mathrm{~m}^{3} / \mathrm{s}$ (scenario $B$ ), while a natural river structure would only cause an additional decrease of $0.1 \mathrm{~m}^{3} / \mathrm{s}$ to $1.1 \mathrm{~m}^{3} / \mathrm{s}$ (scenario C).

In contrast to the results at other model nodes these minor reductions can only be explained by the steepness of slopes and the river bed. On the other hand the changes in river structure and land use have a significant impact on the shape of the flood wave. Land use increased the volume of the 100 year flood by $0.005 \mathrm{Mm}^{3}$ to $0.019 \mathrm{Mm}^{3}$ (Scenario A). In addition a flattened wave would result from a renaturalisation (Scenario C) and decrease the volume necessary for technical flood detention measures.

Reservoir P1 has a maximum available volume of $6600 \mathrm{~m}^{3}$. First damages in the village are starting at a discharge of $0.6 \mathrm{~m}^{3} / \mathrm{s}$. For scenario A a volume of $3900 \mathrm{~m}^{3}$ would be necessary to detain a flood wave of $1.5 \mathrm{~m}^{3} / \mathrm{s}$ to $0.6 \mathrm{~m}^{3} / \mathrm{s}$. For scenario B the same reduction could be achieved with a storage capacity of $2000 \mathrm{~m}^{3}$. In scenario C a volume of only $1800 \mathrm{~m}^{3}$ would be necessary. Assuming average building costs for detention volumes of $30 \mathrm{Euro} / \mathrm{m}^{3}$ this will increase building costs from 54000 Euro for scenario $C$ to 60000 Euro for scenario $B$ and 117000 Euro for scenario A. Splitting of these costs per hectare of farmland means in this catchment 580 Euro/ha for scenario B for 86 ha of farmland in this sub catchment causing this extra run-off. For scenario A the extra costs of detention in contrast to scenario $\mathrm{C}$ are 730 Euro/ha. The difference in buildings costs of 6000 Euro between scenario B and C would represent the extra costs to compensate the effects of river training. For a channel length of $1.1 \mathrm{~km}$ in this particular sub catchment results in extra costs of 5.45 Euro/m.

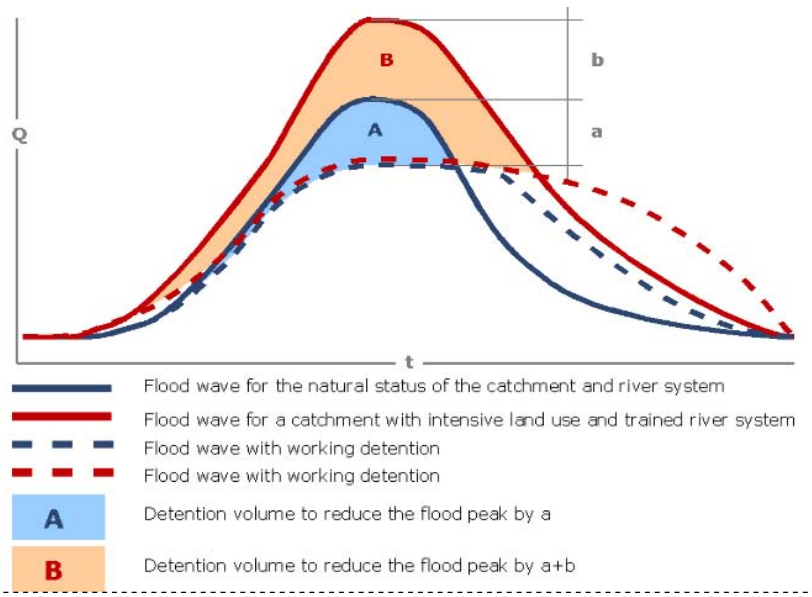

Fig. 6. Impact of volume and peak of flood wave on necessary detention volume in uncontrolled reservoirs.

\subsection{Village of Buchhofen - Consequences for flood damage}

Buchhofen is a settlement in the small Herzogbach valley in the centre of the catchment. It developed along the valley axis and in recent times mainly towards the flood plain. At this point (node 32 ) the catchment is very symmetric and two major branches of the Herzogbach are joining just before Buchhofen.

At this point of the catchment $\left(14.13 \mathrm{~km}^{2}\right)$ agriculture is the predominant form of land use with $69 \%$ of the area. Forestry is the second largest (17\%), followed by grassland $(13 \%)$. Sealed areas are below $3 \%$ of the size of the relevant catchment. Land use as well as river training show a significant impact on the shape and peak of the flood wave. River training increased run-off by $3 \mathrm{~m}^{3} / \mathrm{s}$ (scenario C) to almost $13 \mathrm{~m}^{3} / \mathrm{s}$ (scenario $\mathrm{B}$ ) while land use increased the peak by additional $4 \mathrm{~m}^{3} / \mathrm{s}$ to over $16 \mathrm{~m}^{3} / \mathrm{s}$ (scenario A).

The time shift between the peaks of scenario $\mathrm{A}$ and $\mathrm{C}$ is visible, but not significant (Fig. 5). Flood routing and the modification of the river reaches do not play a crucial role. This can be explained with the short sections upstream and the equal length of river section, resulting in equal travel times of the flood wave from each tributary.

Figures 3,4 and 7 show the impacts of these hydrological changes in the village Buchhofen. Land use mainly affects the high probability low loss events. But taking into account the probability and accumulation of damages over a 100 year period they contribute the majority of damages.

\section{Results}

The study showed, that land use and river structure have an impact on flood related costs. Depending on the location in the catchment, severity of human changes in the river 


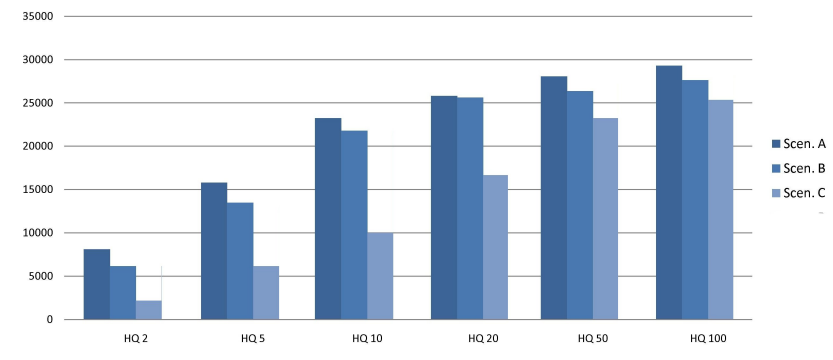

Fig. 7. Affected areas of buildings in the village Buchhofen for different hydrological scenarios.

structure and intensity of agricultural land use changed flood related costs. Flood peaks, relevant volume of a flood wave or both increase in such a way, that either potential damage or costs for effective flood detention rose significantly.

The increase of flood peaks can be explained by different effects.

- Reduced retention capacity of the land cover, especially during spring and autumn after the crop harvest and before seeding.

- Reduced retention capacity of the river bed and especially the flood plain.

- Increased speed of the flood wave in the river system and superposition of flood waves from different branches.

The comparison of peak values in the upper, middle catchment and downstream sections shows that land use especially influences the peak and volume of a flood wave. The changes in the river morphology influenced not only the peak, but also the speed of the flood wave and therefore the superposition of two waves at a junction.

This can be seen very clearly in Fig. 5. For the status quo (scenario A) the run off leads to a nearly perfect superposition of the flood waves from different sub catchments. The scenario $\mathrm{C}$ shows that in former times the level of the peaks was mainly influenced by the land use. The channel structure influenced the run-off speed and as a result the superposition of peaks at the junctions of two branches. This can be explained by the irregular shape of the catchment. Especially towards the outlet the longer branches coming from the upper or western part of the catchment result in longer travel times than the shorter southern tributaries.

Two factors are of interest for the evaluation of floods: the peak of a flood wave and the extent/duration and volume of a wave. The peaks are relevant for the extent of the flood wave in the flood plain (Fig. 7), damage and the necessary elevation of measures for flood defence along the river like dikes and walls. The volume and shape of a wave affects the efficiency of detention measures (Fig. 6).
The analysis showed that land use and river morphology influence both peak and shape. Therefore, three measures can be identified to quantify the externality on a catchment scale:

- The flood damage of scenario A (status quo) minus those of scenario $\mathrm{C}$ (natural situation of catchment and river)

- The costs for flood protection works for scenario A minus those of scenario $\mathrm{C}$

- The costs for detention reservoirs for scenario A minus those of scenario $\mathrm{C}$

It is not always possible to quantify the externality with all three measures: in the Herzogbach catchment no location for larger detention works are available, therefore, it is impossible to quantify the extent and costs of these structures. In larger cities also major supra regional infrastructure can be affected. In such a case it will be difficult to calculate the total damage resulting from indirect and intangible damage.

Although the impacts of land use and river structure are minor from a hydrologic point of view the economic impacts are significant. The accumulation of damage over a certain period (100 years) shows the significant costs resulting from high probability low loss events. Time acts as a leverage and the addition of individual damage over time results in high costs also exceeding the costs of a low probability high loss event (Fig. 7).

\section{Conclusions}

The results of the hydrologic model prove three effects of human interventions in the catchment:

1. Reduced land cover increases surface run-off and, therefore, flood peaks and in addition flood volumes.

2. Natural river structures increase the flow time of flood waves from several branches and reduce the probability of a superposition of flood waves.

3. Natural flood plains store large amounts of water. In combination with decoupled flood waves this can reduce flood peaks.

The consequences of sealing and storm water run-off from settled areas have a similar effect on the development of externalities and need to be assessed in the future in a similar way. Storm water run-off in sewer systems can lead to additional inefficiencies and partial externalities if the costs for infrastructure investments and maintenance are not proportionally shared between causers.

Special impacts of human actions in the flood plain and river basin have been ignored or are difficult to model on a catchment scale: 
- natural depression

- boundary ridges

- drainages

- trenches

- sewers

- field size and structure

As a consequence of the study increased run-off as a result of land use must be seen as an emission. Increased damage or costs for flood defence are, therefore, negative externalities. Applying the polluter pays principles means that land users have either to reduce the level of emission or to compensate costs. The interaction of high probability low loss events with the effects of land use has a leveraging effect. In rural areas already small rainfall events result in damage to buildings or infrastructure. The Herzogbach case study shows clearly that the accumulated damage of these high probability low loss events over time are responsible for the majority of costs.

As a consequence changes in agricultural subsidies or urban development enforced by internalization strategies could have significant impacts on flood prevention through sustainable land use or regain increased costs for flood defence or damage. Internalizations could be an important aspect of flood risk management in small and maybe medium size catchments. The study showed that a combination of engineering modelling techniques and economic analysis could help in flood prevention to reduce societal costs and optimize welfare through reduced floods and sustainable land use.

The evaluation shows that land use has not only a spatial dimension. The results of land consolidation, river training and intensive farming practices cause higher and more intensive floods in downstream areas. These actions have also a inter temporal effect. Because of the temporal variation of precipitation and the low probability of flood events damage can occur years or decades later, than the influencing human impact. Another time factor is the accumulating effect of several measures. While an individual action like the training of a short river section will have a minor and negligible effect, the accumulation of different impacts can significantly change the run-off regime and discharge behaviour of a catchment or river section.

Floods are a restriction for land owners to adequately use their property. They have either to take into account the damage to property and work or avoid or reduce vulnerable uses. In general it can be stated, that human land use and its consequences for river structure and in the flood plain can impact other parties in the downstream section. As shown in this study, related factors, such as river degradation as a consequence of land clearance, cause problems. The increase of floods caused by activities in the upper catchment decreases the use value of land property or increases the damage. The human induced part of flood damage must be split from the natural flood development. Otherwise externalities resulting from land use would be ignored in flood mitigation projects or additional externalities could arise from newly planned measures in the catchment. The flood damage of the situation with an upstream intervention less the damage without an intervention can be used to quantify the externality. Another alternative would be the estimation and difference of mitigation costs for both scenarios.

Different impacts in the past lead to the development of externalities in river basins. "The most significant human interventions in the hydrological cycle have been made over the last decades." (Scheidleder et al., 1996, p. 5). Actions to avoid externalities in the future, therefore, must start at different levels:

- Scenario analysis for projects to estimate supra regional and cumulative effects related to run-off and floods,

- impact assessment of new policies affecting land use,

- better integration of environmental objectives in land use planning and land clearance projects,

- assessment of natural detention in flood mitigation studies.

In general the following counter measures could be applied to reduce the hydrological impacts of land use:

- Application of sustainable farming techniques like direct cropping or intermediate crops (Auerswald, 2002),

- renaturalisation of run-off relevant landscape structures such as ditches to grassed waterways (Fiener and Auerswald, 2003),

- methods for local rain water detention and infiltration in urban storm water management,

- renaturalisation of river sections and

- redevelopment of the natural flood plain (Umweltbundesamt, 2001).

Of course these suggested instruments can only achieve a significant result if they are applied on a large scale, respective on a catchment scale. The effectiveness depends very much on the local climatic and hydrologic conditions and, as mentioned above, the size and structure of the catchment. The broad application of these instruments on a national level also needs a review of actual policies and an evaluation of impacts on other sectors, including an economic impact assessment and cost-benefit-analysis. This would go beyond the scope of this paper and needs the attention of other disciplines, such as economics, agricultural sciences and political sciences. 
Edited by: S. Fuchs, M. Bründl, R. Bernknopf, and T. Glade

Reviewed by: two anonymous referees

\section{References}

Agthe, D. E., Billings, R. B., and Ince, S.: Integrating Market Solutions into Government Flood Control Policies, Water Resour. Manag., 14, 247-256, 2000.

Auerswald, K.: Landnutzung und Hochwasser, in: Rundgespräche der Kommission für Ökologie, 24, Verlag Dr. Friedrich Pfeil, München, 2002.

Cansier, D.: Umweltökonomie, Lucius \& Lucius, Stuttgart, 2. Edn., 1996.

Dorner, W., Spachinger, K., and Metzka, R.: Sustainable land use and the hydrological consequences, in: Academia Danubiana, edited by Kvarda, W., 1, 27-31, Academia Danubiana, 2005.

Dyck, S.: Grundlagen der Hydrologie, Verlag für Bauwesen, 3. Edn., 1995.

Endres, A.: Umweltökonomie, Kohlhammer, Stuttgart, Berlin, Köln, 2. Edn., 2000.

Fiener, P. and Auerswald, K.: Concept and effects of multi-purpose grassed waterway, Soil Use Manage., 19, 65-72, 2003.

Gamper, C. D., Thöni, M., and Weck-Hannemann, H.: A conceptual approach to the use of Cost Benefit and Multi Criteria Analysis in natural hazard management, Nat. Hazards Earth Syst. Sci., 6, 293-302, 2006,

http://www.nat-hazards-earth-syst-sci.net/6/293/2006/.

Herbert, H. and Maidl, S.: Der Strukturwandel in der Landwirtschaft dargestellt an den Dörfern der Gemeinde Buchhofen, in: Deggendorfer Geschichtsblätter, 27, 227-314, 2005.
Ihringer, J.: Softwarepaket: Hochwasseranalyse und -berechnung Handbuch, Institut für Wasserwirtschaft und Kulturtechnik Universität Karlsruhe, 2002.

Kelman, I. and Spence, R.: An overview of flood actions on buildings, Eng. Geol., 74, 297-309, 2004.

Maniak, U.: Hydrologie und Wasserwirtschaft, Springer Verlag, 3. Edn., 1993.

Mankiw, G. N.: Principles of economics, Dryden Press, 2003.

Nujic, M.: HYDRO AS-2D Benutzerhandbuch, 2003.

Pearce, D. W., Atkinson, G., and Mourato, S. (Eds.): Cost-Benefit Analysis and the Environment: Recent Developments, OECD, 2006.

Scheidleder, A., Winkler, G., Grath, J., and Vogel, W. R.: Human interventions in the hydrological cycle, Tech. rep., European Environment Agency, 1996.

Schmidtke, R.: Monetäre Bewertung wasserwirtschaftlicher Maßnahmen - Systematik der volkswirtschaftlichen Nutzenermittlung: Ergebnisse eines interdisziplinären Forschungsvorhabens., Tech. rep., Bayerisches Landesamt für Wasserwirtschaft, 1981.

Umweltbundesamt: Quantifizierung des Einflusses der Landoberfläche und der Ausbaumaßnahmen am Gewässer auf die Hochwasserbedingungen im Rheingebiet, Tech. rep., Umweltbundesamt, 2001.

Umweltbundesamt: Ökonomische Bewertung von Umweltschäden - Methodenkonvention zur Schätzung externer Umweltkosten, Tech. rep., Umweltbundesamt, 2007. 